\title{
ANATOMICAL STUDIES OF THE FRUIT OF ZIZIPHUS RUGOSA
}

\author{
PREMA G*, CHITRA M
}

Department of Botany, Government Arts College, Coimbatore, Tamil Nadu, India. Email: premabot79@gmail.com

\author{
Received: 16 May 2019; Revised and Accepted: 29 June 2019
}

\begin{abstract}
Objective: The objective of this study was to study the anatomical features of the fruit Ziziphus rugosa.

Methods: Surface view, longitudinal, transverse section (T.S), and powder microscopy of the fruits were studied.

Results: The fruit is a drupe and shows vertical, irregular brown markings on the surface. The surface of the seed has irregular and reticulate thick markings of brown. The Longitudinal section(L.S) of the fruit shows thin green epicarp, wide soft mesocarp and dark brown thick endocarp. In longitudinal view, the seed shows a thick conical part, thick wide shell which is hard. In the cotyledon is more or less cordate,white and soft with shallow notch at the upper end. In Transverse section (T.S), the fruit appears circular with soft pericarp, thick dark brown seed coat of sclereids and shows vertically elongated white cotyledons. The epicarp layer is broken at certain places. In the mesocarp, some of the cells have dense tannin content and others have mucilage substance. The middle zone of the mesocarp has large vascular bundles and sclereids. The vascular bundles have large masses of vessels of wide thick walled cells and thick units of phloem elements followed by seed coat. The mucilaginous canals are wide, unbranched and wavy. Some of the mesocarp cells contain dense accumulation of protein bodies. The sclerotesta contains palisade or macrosclereids. The seed consists of two elliptical, flat cotyledons which show dense accumulation of starch grains and small less prominent vascular strand. The powder microscopy of the fruit contain abundant dark mucilaginous substance. Some of the cells are widely elliptical with dark mucilaginous content. There are also circular, thin walled empty parenchyma cells lying along with mucilaginous cells. Fragments of epidermal cells of the pericarp and mesocarp cells are frequently seen. The seed coat epidermal cells are polyhedral with lignified cell walls. They have thin canal like pits of their walls. The circular brachy sclereids were often seen in the mesophyll tissue of the fruit. The ground parenchyma cells with various shapes and size are also
\end{abstract} noticed.

Conclusion: This study revealed the presence of mucilaginous substance, tannin, sclereids, starch grains, and protein bodies. Therefore, this material will be efficient for eliminating some nutritional deficiency diseases.

Keywords: Ziziphus rugosa, Transverse section, Powder microscopy.

(C) 2019 The Authors. Published by Innovare Academic Sciences Pvt Ltd. This is an open access article under the CC BY license (http://creativecommons. org/licenses/by/4. 0/) DOI: http://dx.doi.org/10.22159/ajpcr.2019.v12i8.34167

\section{INTRODUCTION}

The plant Ziziphus rugosa belongs to the family Rhamnaceae. It occurs in all forest districts. It grows up to $6000 \mathrm{ft}$ in the Western Ghats, chiefly in dry deciduous forests. It is a large straggling thorny shrub. Petals 0 ; styles 2;erect small tree or climbing shrub; flowers in pedunculate cymes making panicles on terminal branchlets; leaves large, elliptic, cordate; thorns usually solitary, recurved; drupe 1-rarely 2-celled, stone crustaceous not rugose; disc smooth [1]. It is a famine edible fruit and medicinal plant of the Western Ghats. The ripe deseeded pulp is the source for the preparation of dosa and juice. The pulp and seeds contain proximate, macro- and micro-nutrients, and low toxic elements [2]. The folk medicinal practitioner of Gachabari village in Tangail district, Bangladesh, eats the fruits of Z. rugosa while hunger [3]. The Kodava community in the Kodagu region of the Western Ghats eats the endocarp of $Z$. rugosa as raw and ripened for nutritional source traditionally [4]. This plant is host for Laccifer lacca, a parasitic scale insect [5]. This plant is food for elephant and deer like sambar and spotted eat this fruit [6]. It is a habitat for bee farming in Uttar Kannada district [7]. It contains high concentration of total sugar $(20.7 \%)$ when compared to some other wild and domesticated fruits except sapota [8]. The folk medicinal healers in the districts of Sylhet and Moulvibazar use $Z$. rugosa fruit to treat tumors or cancers. Besides, they use it for sedative, hepatoprotective, blood purifier, and cardiotonic. They take one teaspoon of fruit powder orally with one cup of hot water twice a day [9]. Therefore, the present study aims to investigate anatomical features of the fruit of $Z$. rugosa.

\section{MATERIALS AND METHODS}

\section{Collection of material}

For the research purpose, a twig of the plant Z. rugosa Lam. (Fig. 1) was collected with f1owers and fruits at Sokkalapuram near Pallapatti, Karur district in June 2017. It was identified and authenticated at Botanical Survey of India, Coimbatore. The voucher specimen of the plant refers the No. BSI/SRC/5/23/2017/Tech.570.

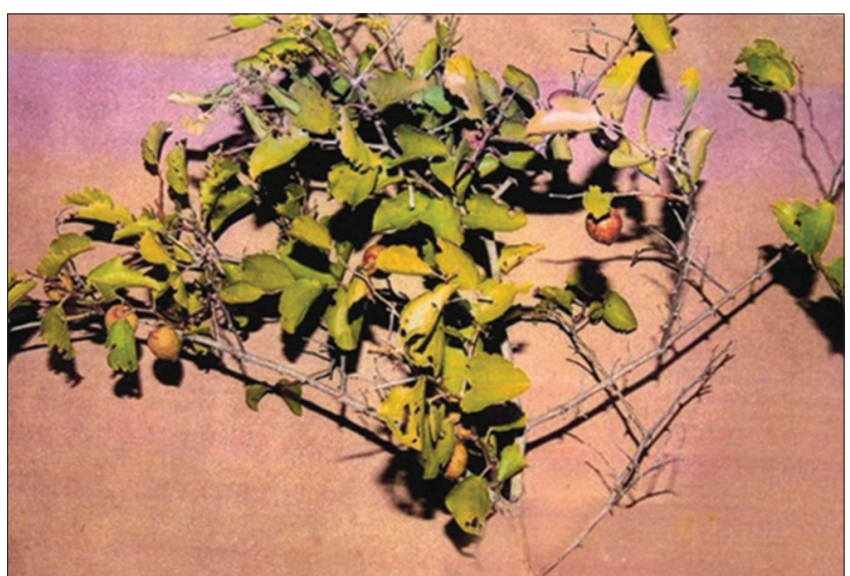

Fig. 1: Twig of Ziziphus rugosa 


\section{Sample preparation}

The collected fruits were fixed in FAA (Formalin $-5 \mathrm{ml}+$ Acetic acid - $5 \mathrm{ml}+70 \%$ Ethyl alcohol $-90 \mathrm{ml}$ ). After $24 \mathrm{~h}$, the specimens were dehydrated with graded serious of tertiary-butyl alcohol [10]. Infiltration of the specimen was carried by gradual addition of paraffin wax (melting point $58-60^{\circ} \mathrm{C}$ ) until TBA solution attained supersaturation. The specimens were cast into paraffin blocks. The paraffin-embedded specimens were sectioned with the help of rotary microtome. Dewaxing of the sections were done by customary procedure [11]. The sections were stained with toluidine blue [12]. Photographs of different magnifications were taken with Nikon Labphoto 2 microscopic unit. For normal observations, bright field was used. For the study of starch grains and lignified cells polarized light was employed. Descriptive terms of the anatomical features are as given in the standard anatomy books $[13,14]$

\section{RESULTS}

The fruit is a drupe. It is ovate in shape with conical end towards the radicle. The surface of the fruit shows vertical, irregular brown markings (Fig. 2a).

The surface of the seed has irregular reticulate thick marking of brown (Fig. 2b). The L.S of the fruit shows thin green epicarp, wide soft mesocarp, and dark brown thick endocarp, which hard shell of the fruit (Fig. 3a). Meanwhile, the seed shows a thick conical part, thick wide shell which is hard. In the cotyledon is more or less cordate, white and soft with shallow notch at the upper end (Fig. 3b).

In transverse section (T.S), the fruit appears circular with soft pericarp, circular thick dark brown seed coat of sclereids, and vertically elongated white cotyledon with wide elliptical and thick conical radicle (Fig. 4a and b).

In surface section (paradermal section of the seed), the seed coat shows numerous brachy sclereids which are short variously shaped, highly thick walled and lignified cells dispersed in thin-walled parenchyma cells (Fig. 5a and b). The pericarp includes epicarp, mesocarp, and endocarp. The epidermis of the epicarp has wide squarish cells with thick cuticle.

Inner to the epidermal layer is three or four tangentially elongated thin-walled cells. Further below comes the parenchymatous mesocarp where the cells are larger, elliptical, and densely filled with tannin
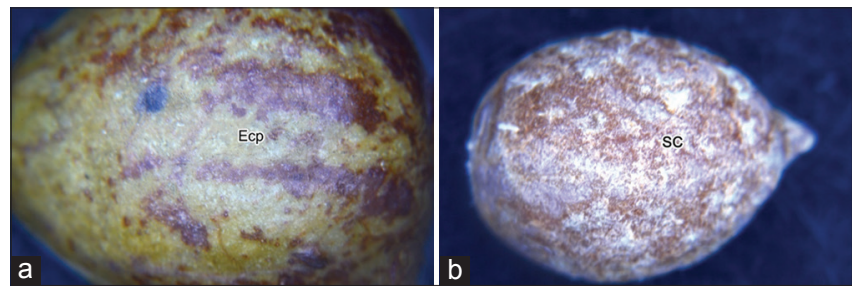

Fig. 2: (a) Surface view of fruit shows brown markings, (b) seed surface shows irregular reticulate markings. Ecp: Epicarp, Sc-seed coat
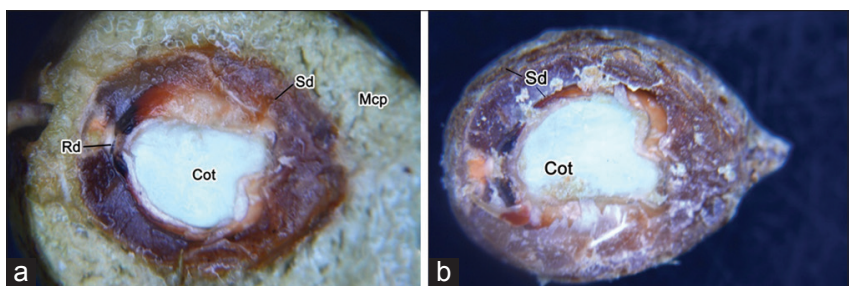

Fig. 3: (a) Longitudinal view of fruit shows soft mesocarp, (b) seed shows cotyledon in its longitudinal view. Cot: Cotyledon, Rd: Radicle: Sd: Seed, Mcp: Mesocarp
(Fig. 6a). The middle zone of the mesocarp has large vascular bundles and sclereids. The vascular bundles have large masses of vessels of wide thick walled cells and thick units of phloem elements followed by seed coat (Fig. 6b and c). Epicarp layer is broken at certain places. The cracks are narrow and not prominent. The mesocarp portion includes polygonal thin-walled compact parenchyma cells. Some of these cells have dense tannin contents and others have mucilage substance. Some of mucilaginous cavities are quite large and circular. The vascular bundles are seen sheathened through the mesocarp (Fig. 7). The mucilaginous canals which are wide, unbranched, and wavy are seen in the pericarp (Fig. 8a). In some of the cells are seen dense accumulation of dark spherical bodies known as protein bodies (Fig. 8b). Sclerotesta is the inner part of the pericarp and outer part of the seed. The cells are vertically elongated, cylindrical compact layer of sclereids and this layer is called palisade sclereids or macrosclereids. After $110 \mu \mathrm{m}$ in vertical place, the cell walls are lignified, due to refringent property of the cell wall. They appear bright under polarized (Fig. 9a). The seed consists of two elliptical, flat cotyledons which occur parallel to each other. The cotyledons have thin epidermal layers on the inner and outer surfaces. They have small compact parenchyma cells which possess dense accumulation of starch grains. There are small, less prominent vascular strands distributed in the cotyledon (Fig. 9b).

\section{Powder microscopy}

The powder preparation of the fruit exhibits the following elements.

\section{Mucilaginous cells}

Long, narrow, elliptical cells containing dark mucilaginous substance are abundant with powder (Fig. 10a). Some of the cells are widely elliptical with dark mucilaginous content. There are also circular, thin walled empty parenchyma cells lying along with mucilaginous cells (Fig. 10b).

Pericarp-epidermal cells of the seed

Fragments of epidermal cells of the pericarp and mesocarp cells are frequently seen in the powder. The seed coat epidermal cells are seen in surface view. The cells are polyhedral in surface view. They are thick walled with lignified cell walls. They have thin canal like pits of their walls (Fig. 11a).

\section{Circular Brachy sclereids}

They are often seen in the powder. These sclereids have fairly thick walls and wide circular lumen. There are narrow canal-like simple pits (Fig. 11b).
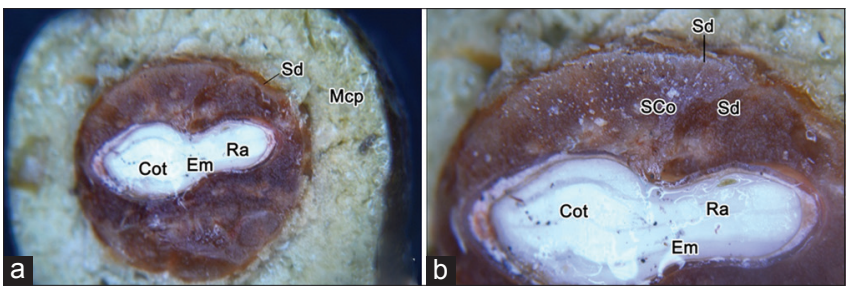

Fig. 4: The longitudinal sections showing cotyledon (a) fruit,

(b) seed, Cot: Cotyledon, Em: Embryo, Ra: Radicle, Sco: Seed coat, Sd: Seed, Mcp: Mesocarp

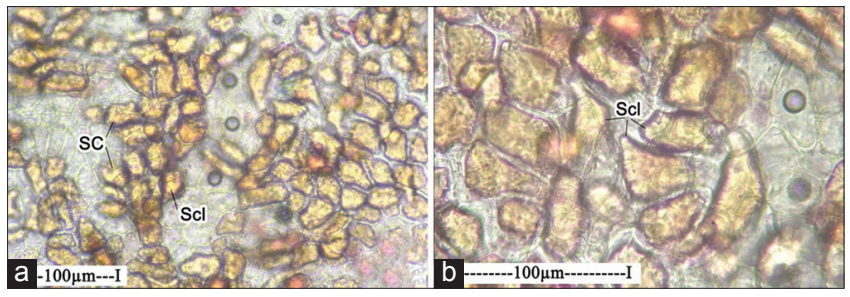

Fig. 5: (a) Seed surface view shows sclereids 20x, (b) enlarged view of sclereids 40x. Sc: Seed coat, Scl: Sclereids 


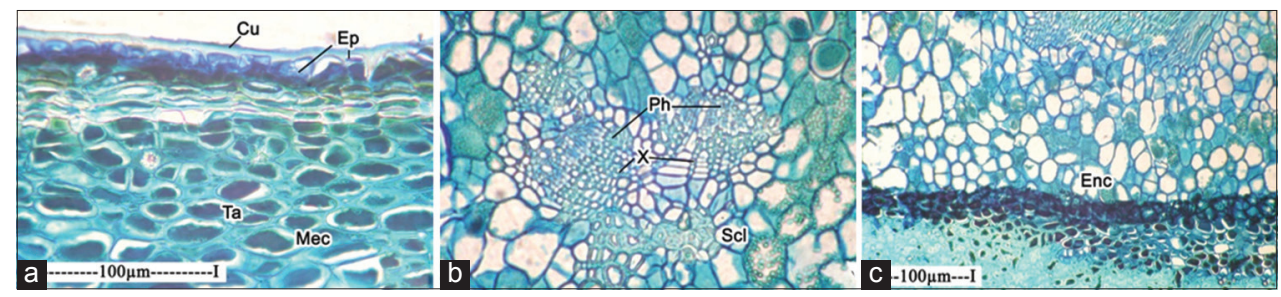

Fig. 6: (a) Fruit T.S shows epicarp 40x. (b) Mesocarp shows vascular strands 20×. (c) Mesocarp shows inner seed coat 20× Cu:cuticle, Ep: Epidermis, Ta: Tannin, Mec: Mesocarp, X: Xylem, Ph: Phloem, Scl: Sclereids, Enc: Endocarp

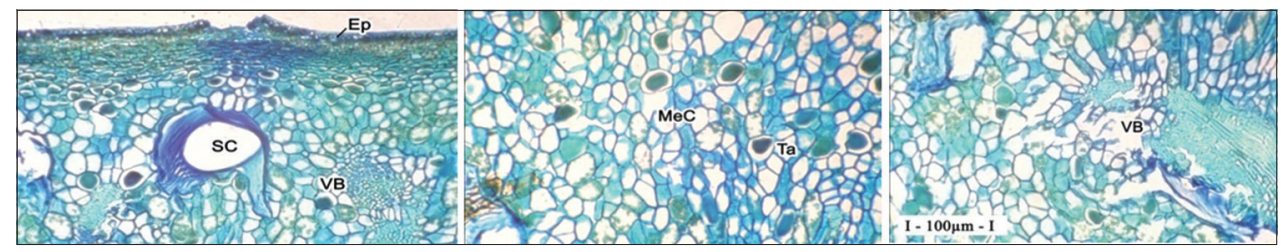

Fig. 7: Transverse section of the fruit shows different regions of the pericarp, Ep: Epidermis, Sc: Secretory canal, Ta: Tannin, Mec: Mesocarp, VB: Vascular bundle

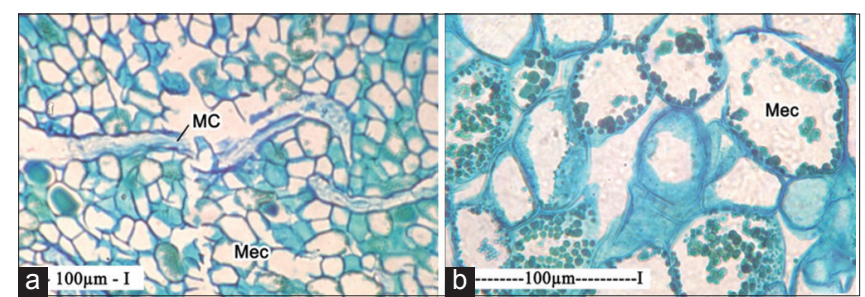

Fig. 8: (a) Mesocarp of the fruit shows mucilaginous canals 10x. (b) Cells of the mesocarp show protein bodies 40x. Mc: Mucilage canal, Mec: Mesocarp
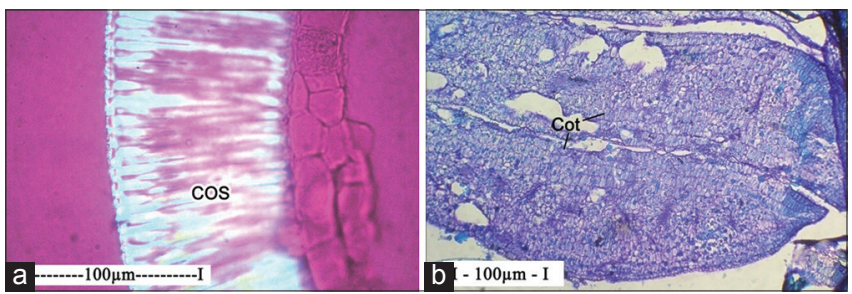

Fig. 9: (a) T.S of testa shows columnar sclereids 40x. (b) T.S of cotyledons show small compact parenchyma cells $10 \times$. Cos: Columnar sclereids, Cot: Cotyledons

\section{Ground parenchyma cells}

Parenchyma cells of various shapes and size are noticed in the powder which are in small clusters. They have thin walls and wide cell lumen. The cell walls are fairly thick and straight (Fig. 11c).

\section{DISCUSSION}

In the present study, the epidermis of the epicarp is covered with cuticle. The parenchymatous mesocarp cells contain dense tannin content, vascular bundles and mucilage canals. The similar results were observed in leaf lamina of $Z$. mauritiana, petiolar cortex of $Z$. rugosa and someother plants of Rhamnaceae and dried ripe fruit of $Z$. jujuba [15-17]. The epidermis covered with cuticle and rarely waxy materials prevent water loss and permit gaseous exchange. Most of the land plants show specialised cells and tissues for mechanical support and other for movement with the plant of materials they synthesize [18]. The mucilage isolated from leaves of Hibiscus rosa-sinensis showed superior skin moisturizing effect to Hibiscus mutabilis in pig skin [19]. Polysaccharide shows the ability to prevent depletion of blood cells and elevated levels of
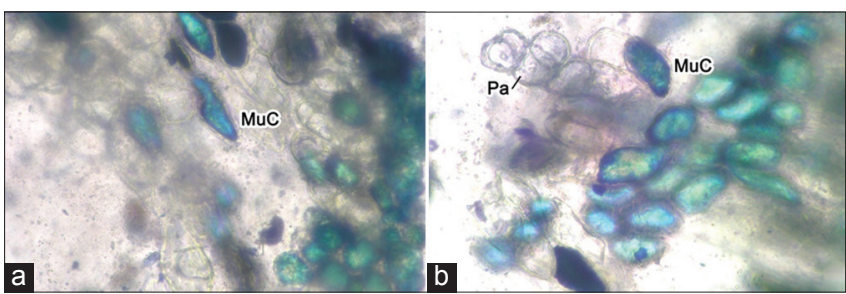

Fig. 10: (a) Powder Microscopy of fruit shows Mesocarp cells 20x. (b) enlarged view of Mesocarp cells 20× Muc: Mucilage cells, Pa: parenchyma
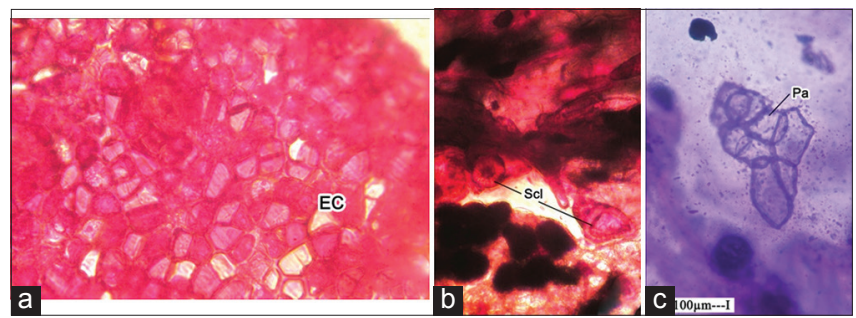

Fig. 11: (a) Seed coat epidermal cells show lignified cell walls 40x.

(b) Sclereids in Mesophyll tissues of fruit show wide circular

lumen 20x. (c) Ground parenchyma cells of mesocarp show straight cell wall -20X Ec: Epicarp, Scl: Sclereids, Pa: Parenchyma

carcino embryonic antigen in dimethylbenz anthracene induced breast cancer rats [20]. The seed coat contains vertically elongated palisade sclereids. The sclereids in the fruit powder show thick walls and wide circular lumen. There are narrow canal like simple pits on their walls. This similar result was carried out in pericarp of Ziziphus xylopyrus [21].

In the present study, the parenchyma cells in the cotyledon and some of the mesocarp cells show dense accumulation of starch grain and protein bodies respectively. This similar result was carried out in leaf powder microscopy of both Ziziphus spina-christi and Ziziphus abyssinica [22]. Protein isolated from leaf of Ficus glomerata showed good antibacterial activity [23]. Microscopic observation of fruit powder show fragments of epidermal cells of pericarp and mesocarp. The seed coat epidermal cells are thick walled with lignified cell walls. The similar results were observed in leaf powder of Ziziphus xylopyrus and methanol and ethanol cold percolation extract of fruit of Ziziphus mauritiana $[24,25]$. 


\section{CONCLUSION}

The present study evaluated anatomical studies in the fruit of Z. rugosa. The epidermis of the epicarp contains wide squarish cells with thick cuticle. The parenchymatous mesocarp cells are densely filled with tannin. The cotyledons have small compact parenchymatous cells with dense accumulation of starch grains.

The powder of the sample contains mucilaginous substance, fragments of epidermal cells of the pericarp and mesocarp. Besides, circular brachy sclereids and small clusters of various shapes and size of parenchyma cells are also there. Therefore, this study would help to determine the quality of the plant.

\section{ACKNOWLEDGMENTS}

The authors would like to thank Botanical Survey of India to identify the specimen and Prof. Jayaraman Director, Plant Anatomy Research Centre, Chennai, to carry out this work.

\section{AUTHORS' CONTRIBUTIONS}

The first author's contribution includes plant collection, identification, journal selection, and preparation of manuscript. Then, the manuscript was corrected by the second author. Both authors read and approved the final manuscript.

\section{CONFLICTS OF INTEREST}

Both authors declare that there are no conflicts of interest.

\section{REFERENCES}

1. Gamble JS. Flora of the Presidency of Madras. Vol. 1. London: Adlard and Sons Ltd.; 2014. p. 219-21.

2. Krishnamurthy SR, Sarala P. Determination of nutritive value of Ziziphus rugosa Lamk: A famine edible fruit and medicinal plant of the Western Ghats. Indian J Nat Prod Resour 2012;3:20-7.

3. Haque MA, Shaha MK, Ahmed SU, Akter R, Rahman H, Imran AH, et al. Use of inorganic substances in folk medicinal formulations: A case study of a folk medicinal practioner in Tangail dt, Bangladesh. Am Eurasian J Sustain Agric 2011;5:415-23.

4. Greeshma AA, Sridhar KR. Ethnic Plant-based Neutraceutical Values in Kodagu Region of the Western Ghats. Biodiversity in India. Vol. 8. New Delhi: Regency Publications; 2016. p. 299-317.

5. Hong D. Flora of China. St Louis: Missouri Botanical Garden Press; 1994. Available from: http://www.efloras.org/florataxon.aspx?floraid=2\&taxon-id=200013475.

6. Available from: https://www.indiabiodiversity.org/species/show/31928.

7. Ramachandra TV, Chandran MD, Jashi NV, Balachandran C. Bee
Keeping Sustainable Livelihood Option in Uttar Kannada, Central Western Ghats. Energy and Wetlands Research Group, Centre for Ecological Sciences, Indian Institute of Science, Bangalore, India: ENVIS Technical Report; 2012. p. 49.

8. Mahapatra AK, Mishra S, Basak UC, Panda PC. Nutrient analysis of some selected wild edible fruits of deciduous forest of India an explorative study towards non conventional bio nutrition. Adv J Food Sci Technol 2012;4:15-21.

9. Akter S, Khairuzzaman MD, Saleem SM, Sattar F, Rahman I, Yesmin MS, et al. Documentation of some folk medicinal practices in Sylhet and Moulvibazar districts, Bangladesh. World J Pharm Pharm Sci 2015;4:176-86

10. Sass JE. Elements of Botanical Microtechnique. New York: McGraw Hill Book Co.; 1940. p. 222.

11. Johansen DA. Plant Microtechnique. New York: McGraw Hill Book Co.; 1940. p. 523.

12. O'Brien TP, Feder N, Mc Cull ME. Polychromatic staining of plant cell walls by toluidine blue-O. Protoplasma 1964;59:364-73.

13. Easu K. Plant Anatomy. New York: John Wiley and sons; 1964. p. 767.

14. Easu K. Anatomy of Seed Plants. New York: John Wiley and Sons; 1979. p. 550.

15. Sivasankari MP, Sankaravadivoo A. Leaf anatomical studies of Z. mauritiana. Int J Curr Res Biosci Plant Biol 2017;4:73-9.

16. Shisode SB, Patil DA. Petiolar anatomy in some Rhamnaceae. Curr Bot 2011;2:22-5

17. Available from: https://www.hmc.usp.org/monographs/ziziphusjujuba-fruit-0-2.

18. Culter DF, Botha T, Stevenson DW. Plant Anatomy: An Applied Approach. $1^{\text {st }}$ ed. Oxford: Black Well Publishing Ltd.; 2007. p. 1-287.

19. Kassakul W, Praznik W, Viernstein H, Hongwiset D, Phrutivorapongkul A, Leelapornpisid P. Characterization of the mucilages extracted from Hibiscus rosa-sinensis and Hibiscus mutabilis and their skin moisturizing effect. Int J Pharm Pharm Sci 2014;6:453-7.

20. Ludas A, Indu S, Hinduja S, Nirmala A, Rajalakshmi M. Anti-cancer potential of polysaccharide isolated from methanolic extract of Tinospora cordifolia stem bark. Int J Pharm Pharm Sci 2019;11:43-7.

21. Singhal U, Goyal A, Solanki NS, Jain VK, Goyal PK. Pharmacognostical study on fruit of Ziziphus xlyopyrus (Retz) Wild. Int J Drug Dev Res 2012;4:263-7.

22. Ibrahim JA, Egharevba HO, Nnamdi RA, Kunle OF. Comparative pharmacognostic and phytochemical analysis of $Z$. spina-christi and Z. abyssinica. Int J Pharm Phytochem Res 2015;7:1160-6.

23. Thapliyal M, Bisht A, Singh A. Isolation of antibacterial protein/peptide from Ficus glomerata leaf. Int J Curr Pharm Res 2016;8:24-7.

24. Jain S, Sharma C, Khatri P, Jain A, Vaidya A. Pharmacognostic and phytochemical investigations of the leaves of Ziziphus xylopyrus. Int $\mathrm{J}$ Pharm Pharm Sci 2011;3:122-5.

25. Rathore SK, Bhatt S, Dhyani DR, Jain A. Preliminary phytochemical screening of medicinal plant Ziziphus mauritiana fruits. Int J Curr Pharm Res 2012;4:160-2. 